\title{
Modern transformation of deserted settlements in the Sudetes Mountains, SW Poland
}

\author{
Agnieszka Latocha ${ }^{1 \otimes}$ \\ ${ }^{1}$ Institute of Geography and Regional Development, Faculty of Earth Science and Environmental Management, University \\ of Wrocław, Pl. Uniwersytecki 1, 50-137 Wrocław, Poland \\ $\bowtie$ agnieszka.latocha@uwr.edu.pl
}

\begin{abstract}
The aim of the study was to present and to classify current processes and phenomena which are observed within the depopulated villages in the Kłodzko region in SW Poland, to assess the present conditions, functions and meanings of deserted settlements, and to forecast their potential further transformations. The study was based on diverse cartographic sources, field investigations, inventories and interviews, historical documents and current spatial development plans. The current processes and phenomena occurring in the highly depopulated or deserted villages are spatially very diverse in terms of their types and dynamics. They include: afforestation (re-wilding), return to agricultural use (limitation of the secondary succession), new houses or the renovation of the old ones, partial restoration of the sacral landscape, large-scale tourist infrastructure and educational initiatives (educational trails, eco-museums, information boards). However, some areas remain forgotten and neglected. These processes often co-occur with each other and they may be diverse in different parts of the village. In the current transformations of the abandoned areas the main focus is on local economy or nature protection while the cultural landscape of the deserted villages is hardly appreciated as an important value itself. The potential future transformations of the depopulated areas will be multidirectional with the tendency to polarization. Some areas will be subject to an increased human pressure, especially due to the new developments in housing and large-scale tourist infrastructure, the other areas will remain out of the way allowing for using their potential as "archives" of traditional cultural landscapes.
\end{abstract}

\section{Highlights for public administration, management and planning:}

- The current transformations of the deserted villages are spatially very diverse and various phenomena can co-occur in different parts of the villages.

- There is an increase in the interest in the local history and the values of the cultural landscapes of the abandoned villages are discovered but their educational, cultural and touristic potential is not yet fully used.

- The deserted villages represent a valuable bio-cultural heritage, which should be better managed, protected and promoted.

- The observed processes in the abandoned areas result mainly from the individual decisions and they are not the result of a broader cultural landscape protection policy.

- Many of the depopulated villages have recently started to play a tourist and recreational function but this process should be controlled to avoid the excessive expansion of built-up areas or their improper scale or architecture.

\section{Keywords}

Depopulation,

Abandoned villages, Cultural landscape,

Heritage,

Land use change,

Kłodzko region

Received:

07 September 2020

Received in revised form: 02 December 2020

Accepted:

08 December 2020

The paper was originally presented during the thematic session "Settlement desertion and cultural landscape transformations: connections between past and present" at the $5^{\text {th }}$ Landscape Archaeology Conference held in Newcastle and Durham, UK, in 2018. Selected presentations from the session are now published in this volume as thematic papers exploring the contribution of historical geography, landscape archaeology and landscape heritage studies to preservation, management and planning of historical landscapes. 


\section{Introduction}

Depopulation is currently one of the main problems observed in many parts of the world, affecting both urban and rural areas (e.g. Shrinking regions... 2008; Wang et al. 2019). The growing number of the scientific literature discussing that topic also proves the increased importance of that problem in the recent decades (Rodriguez-Soler et al. 2020). The variety of the research on depopulation is very broad, ranging from the identification of its causes and driving forces (McLeman 2011; Li et al. 2019; Merino \& Prats 2020), through studies on the impact of depopulation on the environment (e.g. Foucher et al. 2019; MacDonald et al. 2000), up to the searching for solutions and policies to cope with the problem (Boesch et al. 2011; Pinto-Correia et al. 2016). The research on land abandonment is a very widely discussed topic within the studies on land-use/land cover and landscape changes, which were triggered by the depopulation (e.g. Plieninger et al. 2016; Lasanta et al. 2017). The phenomenon of deserted villages (and towns) is the most extreme result of the depopulation and land abandonment and it has also gained importance in the recent research (Filipe \& Mascarenhas 2011; Mares et al. 2013; Hons 2014; Latocha 2015; Di Figlia 2016; Wolski 2016; Jaszczak et al. 2018; Güler \& Kâhya 2019). The causes of depopulation are both global, linked to the universal trends like globalization, urbanization, global market, industrialization, EU policies and subsidies etc., but they are also highly related to the sitespecific constraints, especially to the local environmental factors (Súl'ovský et al. 2017; Telbisz et al. 2020). Therefore the trajectories of depopulation and land abandonment are different in various regions. The Mediterranean region is one of the most severe affected by depopulation of rural areas in Europe (e.g. Collantes \& Pinilla 2011; De Haas 2011). In the Central-European context, which is in the focus of the presented paper, the depopulation and land use changes, including land abandonment, have been intensified in the post-World War II period by the political drivers and socio-economic transformations, such as large-scale forced displacement of former German inhabitants, and any other inhabitants in the border areas, especially along the "Iron Curtain", communism regime and nationalization of land and state economies, political and economic changes in the 1990s related to the opening to the free market economy, privatization of land and business entities, joining the European Union in 2004 with new opportunities to financial support and subsidies, and, eventually, joining the Schengen zone in 2007 which opened up the possibilities of the transborder cooperation (Kučera \& Chromý 2012; Bezák \& Mitchley 2014; Bičík et al. 2015; Lieskovský et al. 2015; Štastná et al. 2015; Skokanová et al. 2016; Bucała-Hrabia 2017; Flaga \& Wesołowska 2018; Bičík et al. 2019; Affek et al. 2020).

In the recent years the change of perception of the deserted areas can be observed. The importance of the cultural and ecological values of the abandoned traditional rural areas is highlighted and re-interpreted (Spurný 2006; Kučera \& Kučerová 2012; Mares et al. 2013; Di Figlia 2016). The deserted villages are perceived as a potential for a new type of multifunctional development of rural areas, with the main focus on tourism developments (Filipe \& Mascarenhas 2011; Jaszczak et al. 2018). The need to re-appreciate the abandoned areas is also formulated by many authors because such traditional rural landscapes are a very important part of the bio-cultural heritage, which is often associated with regional architecture, historical pattern of land use and high level of biodiversity. Therefore they should be better managed and protected (Antrop 2005; Špulerová et al. 2010; Agnoletti 2014).

In the above presented context, the paper discusses the depopulation, land abandonment and settlement desertion on the example of the Sudetes Mountains in SW Poland, which represent both the site-specific and typical processes and phenomena for the Central-European mid-mountains and post-communist countries. The region was subject to large-scale depopulation, which started in the 1880s and intensified after the 2nd World War due to various political, socio-economic and environmental reasons (Zagożdżon 1990; Ciok 1991). In detail they can be grouped in several types of factors, which were either specific for different depopulation phases or occurred simultaneously. They included as follows: (1) environmental factors not favorable for agriculture in mountain areas, such as poor, stony and shallow soils, steep slopes, harsh environmental conditions; (2) outflow from high elevated and overpopulated agricultural lands to cities with developing industries; decline of craft and cottage industry, and mining - these factors were especially important at the end of the $19^{\text {th }}$ century and in the first decades of the $20^{\text {th }}$ century; (3) state border changes; exchange of population; limited re-settlement - factors essential in the postwar period (1945-48), when the autochthonous German inhabitants were replaced by the new-settlers from various parts of Poland; (4) breaking of tradi- 
tional knowledge in agriculture; difficulties in adjusting to mountain environment; improper agricultural policies and treatments resulting in soil erosion; restrictions in borderland; decreasing role of small towns as local centers; lack of renovation of infrastructure, housing and industrial facilities; lack of new investments; political transformations resulting in changes in land ownership; decline in local services, industries and crafts; ageing of population. The last group of depopulation factors was especially influential in the 1950-1960 but the depopulation trend can still be observed in many parts of the Sudetes nowadays, mainly due to the outflow of the young generation from rural areas. However, the present depopulation rate is much slower than before and in some areas the reverse trend can be even observed showing a slight increase in population in rural areas due to recent migrations from the cities to the more natural areas (Szmytkie \& Tomczak 2015).

Nevertheless, the long-lasting and intense depopulation resulted in the substantial transformations of the cultural landscape, and especially changes in land use and settlement network. There is a large-scale increase in forest and grassland at the expense of arable lands in the entire Sudetes. Many villages have visibly shrunk and some have entirely disappeared, especially these ones located in higher elevations and in the more remote areas, as well as smaller units like hamlets and colonies. The definitions of vanishing and deserted villages were proposed already at the end of the 1970s (Chachaj 1978). In spite of depopulation, land abandonment, decline of settlements and development of secondary succession of vegetation, the numerous traces of past land use and more intense and broader land management are still readable in the contemporary cultural landscape in the deserted areas. They include anthropogenic landforms and features related to various types of the past economic activities such as agriculture, mining, quarrying, water management, transportation, ore processing, industry and crafting (Latocha 2015). The abundance and diversity of the remains of the more intense human occupancy of the mountain areas in the past entitles to recognize the Sudetes Mountains as a valuable reserve of the past traditional cultural landscapes, according to the definition by M. Antrop (2005). Unfortunately, for many decades the abandoned villages were neglected and forgotten, and the cultural potential of the deserted areas was not appreciated at all.

However, in the recent years a substantial political and socio-economic changes, which occurred in Poland after the transformations of the year 1989, and joining the European Union (2004) and Schengen zone (2007), have also affected to some extent the current perception and management of the deserted areas, similarly to processes observed in other post-communist countries.

The aim of the study is to present and classify the current processes and phenomena which are observed within the depopulated areas and to assess the present conditions, functions and meanings of the deserted villages, and to predict what are the potential paths of their further transformations. To achieve these goals, the Kłodzko region was selected as the case study for the detailed analysis. The selection of the study area is justified by both the most intense depopulation of the Kłodzko region in the entire Sudetes Mountains (Miszewska 1993), including the largest number of deserted villages, and the most intense and diverse current transformations of the abandoned areas, which is discussed in this paper.

\section{Materials and methods}

The initial part of the research was the selection of the most depopulated and deserted villages in the Kłodzko region. The calculation of the scale of depopulation was based on the comparison between the maximum population in each village in the prewar period and the minimum number of inhabitants noted in the post-war period. The data was based on all the available censuses from the mid-19 ${ }^{\text {th }}$ century until present, which were conducted every 10 years on average. The details on the statistical sources and the results of the calculation of depopulation were presented and discussed in previously published studies (Latocha et al. 2018). The analysis included only villages which were mentioned in the censuses, which means that the smaller units such as hamlets and colonies are not considered as separate settlement units because in the censuses they were classified as parts of the larger villages.

There are 29 villages selected for the present study, which include all the villages with the depopulation of $90 \%$ and more (Fig. 1). The main part of the research was based on the field surveys, including inventories of the current land use of the deserted settlements, state of the preservation of the remains of former buildings and other man-made constructions, as well as interviews with local inhabitants, also in the nearby areas. The historical and contemporary cartographic materials (topographic maps Mestischblatt 1:25 000, 1880s; 
Official State Database of Topographic Objects, BDOT10k, 2013), ortophotomaps and photographs from different time periods were used in the study in order to assess the landscape changes within the last 130 years. Moreover, the historical maps (Messtischblatt) were the crucial source materials for the field surveys - the extent of former built-up areas and arable lands was reconstructed on their basis in order to verify in the field the present use of the deserted villages. Additionally, the analysis of the current spatial development plans and documents, and statistical data from the local and regional authorities (i.e. number of permits for building new single family houses) were the source materials for forecasting the potential future transformations of the depopulated villages.

\section{Depopulation in the study area}

The Kłodzko region is a historical region, with an area of $1643 \mathrm{~km}^{2}$, clearly delimited by natural boundaries, which are defined by the mountain ridges. To a large extent, the geographical boundaries correspond with the extent of the historical Kłodzko County (Graftschaft Glatz) and with the present administrative unit of the Kłodzko poviat. There are numerous historical and geographical studies on Kłodzko region conducted by Polish, Czech and German researchers (e.g. Bernatzky 1984; Herzig \& Ruchniewicz 2008; Semotanová et al. 2015). Some of them focus especially on the changes in demography and land use, and the resulting transformations of the landscape (see more references in Latocha et al. 2018). The depopulation of the Kłodzko region between the mid-19th century and present times was the most intense in the entire Sudetes Mountains (Miszewska 1993). Depopulation affected all villages in the study area, although its rate and spatial distribution was very diverse across the region. In 131 settlements (70\%) - out of the total 185 settlements in the Kłodzko county (174 villages and 11 towns) included in the analysis - the decrease in population between pre-war maximum and postwar minimum was $50 \%$ and more, and for one third of the settlements - more than $80 \%$. The 29 villages selected for the analysis presented in this paper (with depopulation level at 90\% and more) constitute $17 \%$ of all villages in the Kłodzko region (Table 1). They are located in various parts of the region but mainly in higher elevations and in the isolated places with difficult access (Fig. 1). Seven villages out of this group reached $100 \%$ of depopulation in the studied period although some of them were recently re-settled with few permanent or temporary residents (Table 1 ).

\section{Results - transformations of the deserted settlements}

The field survey of the selected 29 deserted or highly depopulated villages proves that current state of these areas is spatially very diverse. They are subject to different processes and phenomena leading to either large-scale transformation or stabilization and sometimes even re-appreciation of the remains of the past cultural landscape. The current phenomena observed in the deserted villages in the Kłodzko region can be grouped as presented in the Table 2 and Fig. 2. In some villages several phenomena can be observed in the adjacent areas (Fig. 3).

Table 1 The most depopulated villages in the Kłodzko region; explanation of calculation in the text.

\begin{tabular}{|c|c|c|}
\hline & Village & $\begin{array}{c}\text { Depopulation } \\
(\%)\end{array}$ \\
\hline 1 & Biała Woda & 100,0 \\
\hline 2 & Czerwony Strumień & 100,0 \\
\hline 3 & Karpno & 100,0 \\
\hline 4 & Piaskowice & 100,0 \\
\hline 5 & Rogóżka & 100,0 \\
\hline 6 & Wrzosówka & 100,0 \\
\hline 7 & Zimne Wody & 100,0 \\
\hline 8 & Poniatów & 99,4 \\
\hline 9 & Rudawa & 99,1 \\
\hline 10 & Marcinków & 99,0 \\
\hline 11 & Mostowice & 97,5 \\
\hline 12 & Taszów & 97,3 \\
\hline 13 & Janowa Góra & 97,2 \\
\hline 14 & Potoczek & 96,5 \\
\hline 15 & Niemojów & 96,3 \\
\hline 16 & Sienna & 96,0 \\
\hline 17 & Studzienno & 95,5 \\
\hline 18 & Huta & 95,5 \\
\hline 19 & Leśna & 94,8 \\
\hline 20 & Bieganów & 94,7 \\
\hline 21 & Pasterka & 94,5 \\
\hline 22 & Witów & 94,0 \\
\hline 23 & Szklary & 93,9 \\
\hline 24 & Lesica & 93,7 \\
\hline 25 & Bielice & 93,4 \\
\hline 26 & Jodłów & 91,7 \\
\hline 27 & Jerzykowice Małe & 91,0 \\
\hline 28 & Szczawina & 90,2 \\
\hline 29 & Gniewoszów & 90,1 \\
\hline
\end{tabular}

Source: own elaboration based on the pre-war and post-war censuses. 


\section{sciendo}

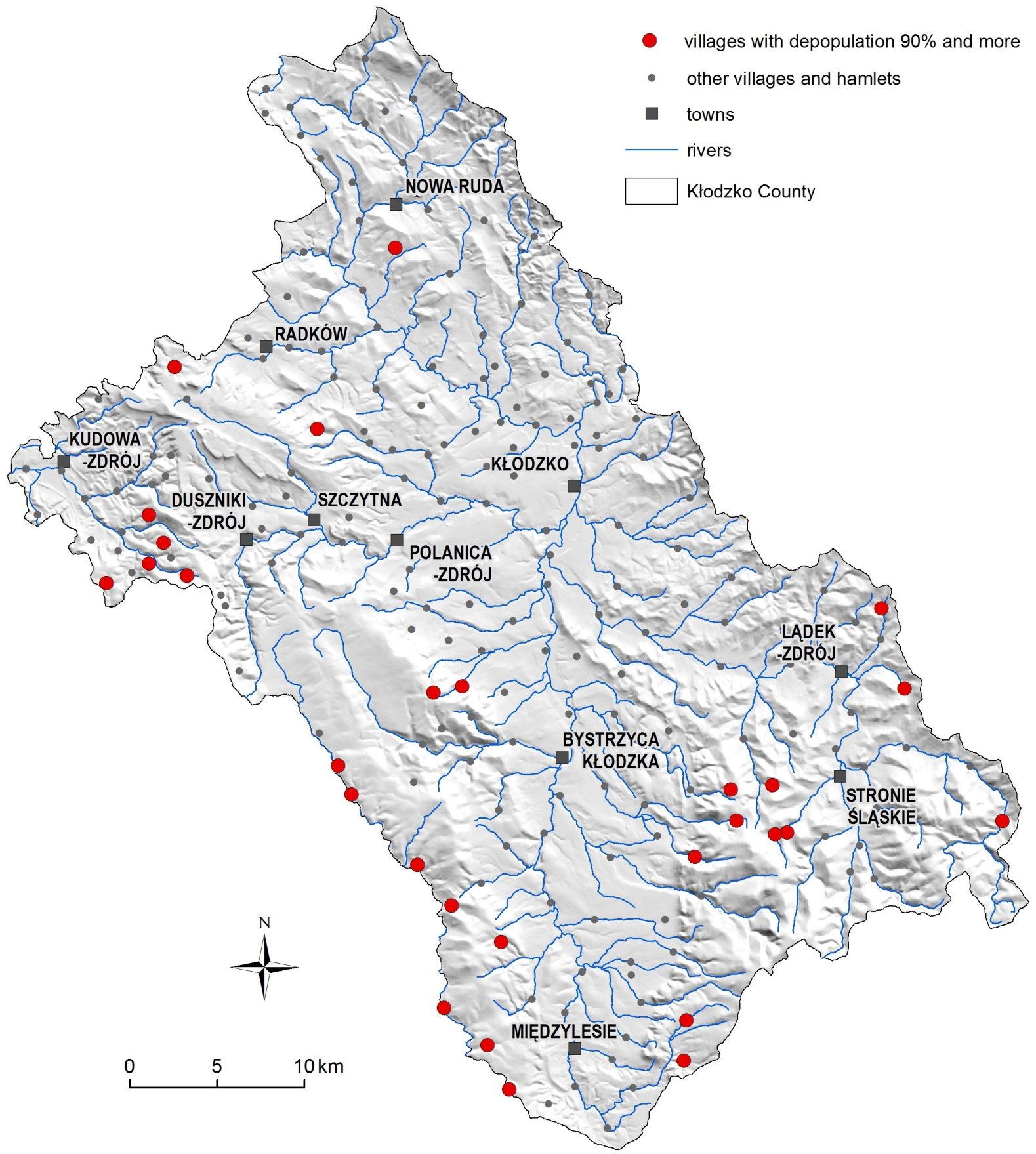

Fig. 1 Study area with villages selected for the investigation (with depopulation $90 \%$ and more); see also Table 1 . Source: own elaboration based on the pre-war and post-war censuses.

\subsection{Re-wilding}

The agricultural land occupied 50\% of the Kłodzko county in the second half of the 19th century, while nowadays it covers only 23\% (Latocha et al. 2016). The forested areas increased from $36 \%$ to $48 \%$ and grasslands - from $9 \%$ to $24 \%$. In the depopulated villages most of their former ploughing grounds are now occupied by pastures and hay meadows, and some of them are entirely or partly overgrown by forests and/or shrubs. It is worth noting that most of these transitions in land use developed as a spontaneous secondary succession of vegetation on abandoned former arable lands. In some areas we can observe different stages of succession, which is still progressing in the deserted villages (Figs. 3 and 4A). Only small part of the forests (up to several percent locally) were 
Table 2 Classification of the current processes and phenomena which are observed within the deserted villages in Kłodzko region (29 villages in total; in different parts of the village various processes/phenomena can be present). See text for further explanations.

\begin{tabular}{lll}
\hline & Type of process/phenomenon & Number of villages \\
\hline 1. & Re-wilding & 29 \\
2. & Stopping/reduction of the secondary succession & 27 \\
3. & Educational paths, eco-museums, information boards & $8(2+2+4)$ \\
4. & Restoration of sacral landscape & $18($ in $13-$ only partial renovation $)$ \\
5. & Renovations \& new housing & $25 / 21$ \\
6. & Large-scale tourist infrastructure & $3+(1$ potentially in future $)$ \\
7. & Villages for sell & $1+(2-$ only partial or planned but not successful $)$ \\
\hline
\end{tabular}

Source: own elaboration.

intentionally planted on the former fields (oral information from the manager of the local Forest Authority). The period with the least intensive economy and the largest share of set-aside lands was the 1990s (Nadolna 2012). As a result of the varied start time for the development of secondary succession on agricultural land as well as local differences in the environmental conditions, the landscape of the Kłodzko region at the end of the 20th century represented a highly diverse mosaic of vegetation patches in different stages of succession, which resulted in the development of many ecotones and large diversity of habitats, with the seminatural grasslands developed on the former arable lands as the richest one in terms of species. The widespread natural succession can be interpreted as a spontaneous re-wilding of the previously maintained and human-controlled land, which can also be described as the "new wilderness" (Bičík et al. 2015). The resulting changes in vegetation and habitats contributed to the establishment of numerous formally protected areas in the Kłodzko county, which include: 1 national park, 2 landscape parks, 2 areas of the protected landscape and 20 areas of the European Ecological Network NATURA 2000. Most of the deserted villages are located within the protected areas or within their buffer zones and in their nearest surroundings.

\subsection{Secondary succession has been locally stopped and/or reversed}

Although the above-mentioned secondary vegetation succession can still be observed in some abandoned areas, in some other places is has been locally stopped or even reversed (Fig. 4B and C). It means that the newly encroaching shrubs and young trees were removed and the land has been restored to use. These processes are primarily related to the financial support within the frames of the EU agri-environmental schemes and other direct payments for the less-favored areas. They have been available since 2004 when Poland became a member state of the European Union. Although the interest of farmers in joining the agri-environmental scheme in its first period of implementation (2004-2006) was very low, it has largely increased in the following period (2007-2013). The most popular packages and variants selected by farmers in the Kłodzko region were related to maintaining the extensive permanent grasslands and especially the hay meadows and pastures. These options dominated not only in the number of farmers joining the schemes but also in the total area covered by the program, which visibly affected the landscape in the previously abandoned areas (Fig. 4C). Currently, the Kłodzko poviat belongs to the areas with the largest share of permanent grassland in the whole Dolny Śląsk (Lower Silesia) voivodship (Kutkowska \& Berbeka 2014). Semi-natural grasslands, which have developed on the former arable land, are characterized by high species richness, including rare and protected species of plants (Nadolna 2012) and birds (Mikusek 2011). The recent increase in the number of cattle grazing in the former agricultural lands of abandoned villages can also be observed in the study area.

\subsection{Educational paths and information boards}

The deserted settlements, along with their rich and diverse inventories of the anthropogenic landforms and features related to former human activities, can be treated as the surviving laboratories of the past cultural landscapes. They have a high potential for implementing the idea of "reading the landscape", which is still not very well developed in Poland. It gives the opportunity to understand the history hidden behind the preserved landforms and features. Unfortunately, the deserted areas in the Sudetes Mountains and their cultural heritage were almost totally forgotten in the postwar period and some elements of that heritage were 


\section{sciendo}

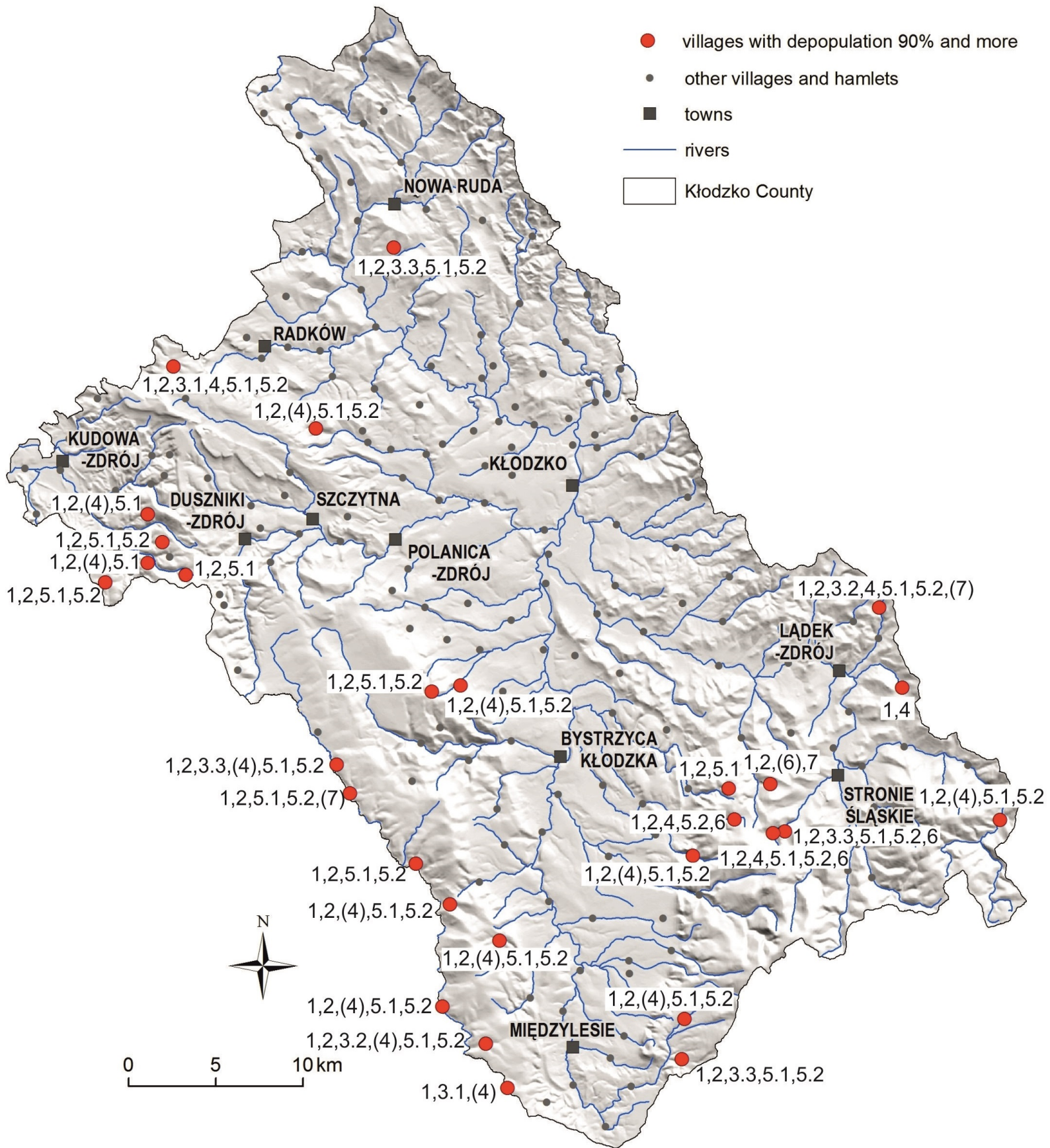

Fig. 2 The depopulated villages classified according to the current processes and phenomena as defined in Table 2: 1 - re-wilding; 2 - stopping/reduction of the secondary succession; 3 - education (3.1 - educational paths, 3.2 eco-museums, 3.3 information boards); 4 - restoration/renovation of sacral landscape, (4) - only partial renovation; 5 - housing (5.1 - renovation of old buildings, 5.2 - new housing); 6 - large-scale tourist infrastructure, (6) - potential in future according to the spatial development plans; 7 - villages for sell, (7) - only part of the village sold or selling planned but not successful.

even purposely destroyed or removed as it was perceived as the "enemy's" heritage (oral information from numerous inhabitants). However, in recent years the increase in the interest in the history of the region can be observed and the pre-war heritage is re-appreciated and sometimes also renovated or reconstructed. Two of the deserted villages have received their second, symbolic lives when the educational paths were created through their remains (Czerwony Strumień, Ostra Góra - part of Pasterka) and two other villages were turned into eco-museums (Wrzosówka, Lesica). In four other places we can find the educational boards with focus on the history of the settlement, usually with 


\section{S sciendo}

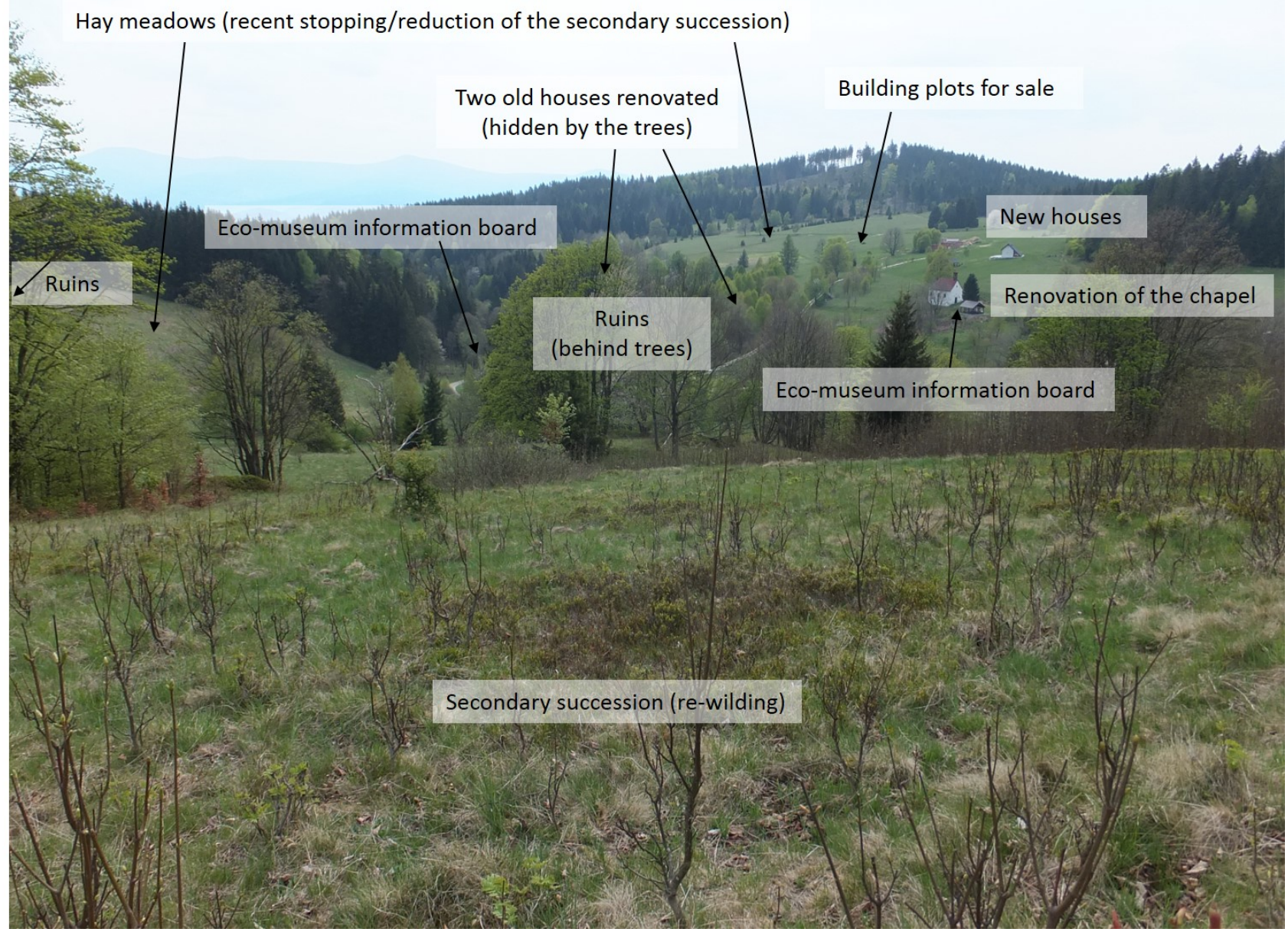

Fig. 3 The example of diverse phenomena occurring within one deserted village (Wrzosówka case study). Source: photo by A. Latocha 2020
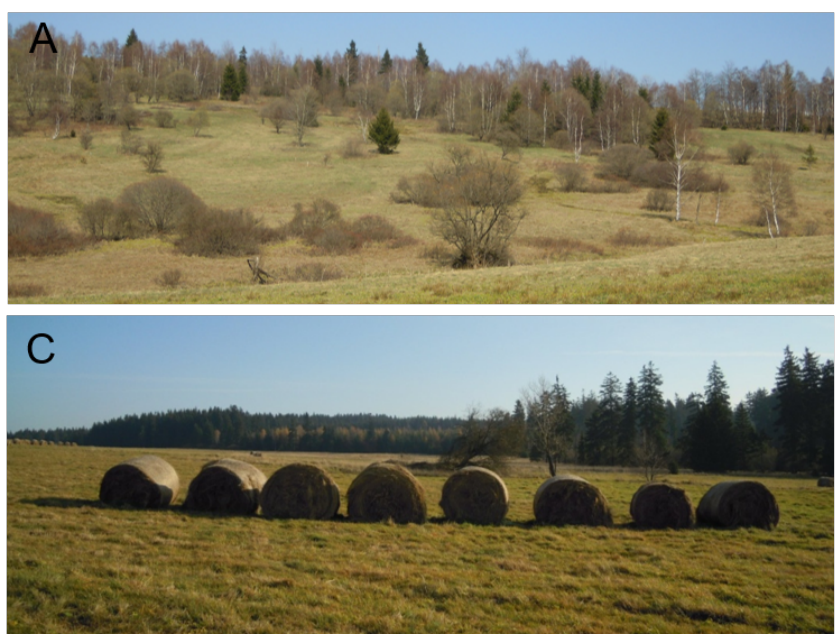

Fig. 4 Transformations of former arable lands: A - development of secondary plant succession, B - implementation of agri-environmental schemes and stopping of plant succession, C - hay meadows. Source: photo by A. Latocha 2014

old photographs explaining the changes in the landscape (Potoczek, Sienna, Janowa Góra, Mostowice). The two educational paths - nature-historical trail

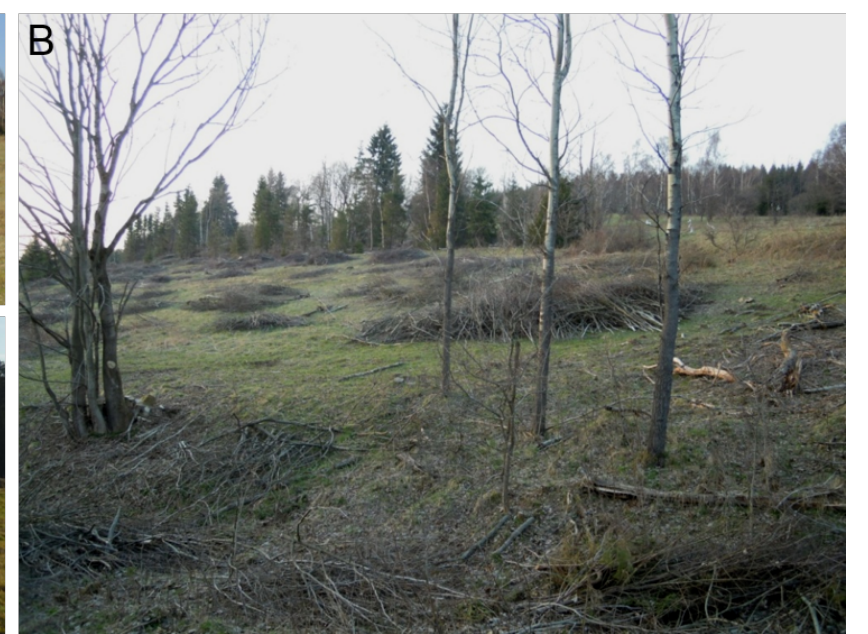


cal NGO in the first case and the transborder cooperation between Czech NGO and Stołowe Mountains National Park in the second case. All the other initiatives to establish explanatory and interpretative boards in the depopulated villages were also bottom-up initiatives coordinated either by regional NGOs, local communes or local individual leaders.

\subsection{Local restoration of sacral landscape}

Kłodzko region is very rich in sacral landscape, including many churches and sanctuaries, as well as numerous chapels, crosses and statues of saints along roadsides (e.g. Semotanová 2009). The traces of the sacral landscape are also found in the deserted villages, and in some areas they are the only remains of the former built-up areas in the village. However, their state of preservation is very diverse in different locations. For example, although there are many new guesthouses and hotels in Janowa Góra, the church in the village is abandoned and ruined (Fig. 6A). In contrary, in the deserted village of Karpno there are no new developments except for renovation of the small forest chapel, which has recently become a popular destination for tourists and local people from the nearby town (Lądek-Zdrój) and villages. Similarly, in the deserted village of Wrzosówka, the chapel has recently been renovated by the volunteer Fire Department and it is nowadays maintained by the local firemen and inhabitants of the nearby town (Lądek-Zdrój) (Fig. 6B). In Czerwony Strumien the ruins of the small church has been included into the educational path and make for the most important stop and an icon of that historical trail through the deserted village. The increase in number of the recently renovated small-scale sacral architecture along roadsides can also be observed in the Kłodzko region, including the areas of depopulated villages. However, there are still many sites which need renovation (Fig. 6C, D). It should also be mentioned that some of the churches have been renovated with the financial support by Germans who previously lived in the region.

\subsection{Renovations \& new housing}

In recent years there is a substantial increase in new housing in the entire Kłodzko region. It started after the socio-economic changes in Poland took place in 1989 but its most intense phase has been noted from the 2000s (Latocha 2017). Although the new houses are concentrated mainly in the suburban zones of towns, and especially spa-towns, as well as in the central parts of the region in the vicinity of the main transportation routes, this phenomenon can also be observed in the previously abandoned and highly depopulated villages. The single family houses are built both for permanent and temporary living. Especially the increase in the so called "second homes" is noted in the abandoned areas. Although such locations are usually remote and isolated they have a high potential of landscape and natural values which attract people from large cities searching for more quiet and natural environment. Only in 7 out of 29 deserted villages analyzed in this study there was no new house built in the entire post-war period. However, in 4 out of these 7 villages the renovation of the old farmsteads took place instead. The renovation of old buildings is a wide spread process in the entire region in the recent years and it can be observed also in many of the highly depopulated villages. The renovated pre-war houses are used both as second homes and as places for permanent living. What is worth mentioning is that most of the new owners try to preserve the traditional style of the regional architecture during the renovation, which is a very rare case as far as the newly built houses are concerned.

\subsection{Large-scale tourist infrastructure}

There are several "hot spots" for development of the new tourist infrastructure in the Kłodzko region in the recent years. They have developed mainly as skiing centers but more facilities were successively added for all-year round tourist activities such as hiking and biking. One of the largest tourist centers and with the fastest dynamics of growth has developed in the vicinity of the Czarna Góra Mountain in the Śnieżnik Massif. The new infrastructure, including new sport areas, hotels, guesthouses, restaurants and other services, has developed on the grounds of three neighboring deserted villages. Two of them (Sienna and Janowa Góra) had depopulation at the level of $96-97 \%$ and the third one, Biała Woda, lost the entire population and buildings for several decades. At present, the abandoned areas of the villages have been entirely transformed by new developments, and the increase in accommodation (number of beds) is the largest in the entire Kłodzko region (Szmytkie \& Tomczak 2017). In this case, the deserted villages and their related arable lands have received completely new functions and spatial structure (Fig. 7). 


\section{Sciendo}
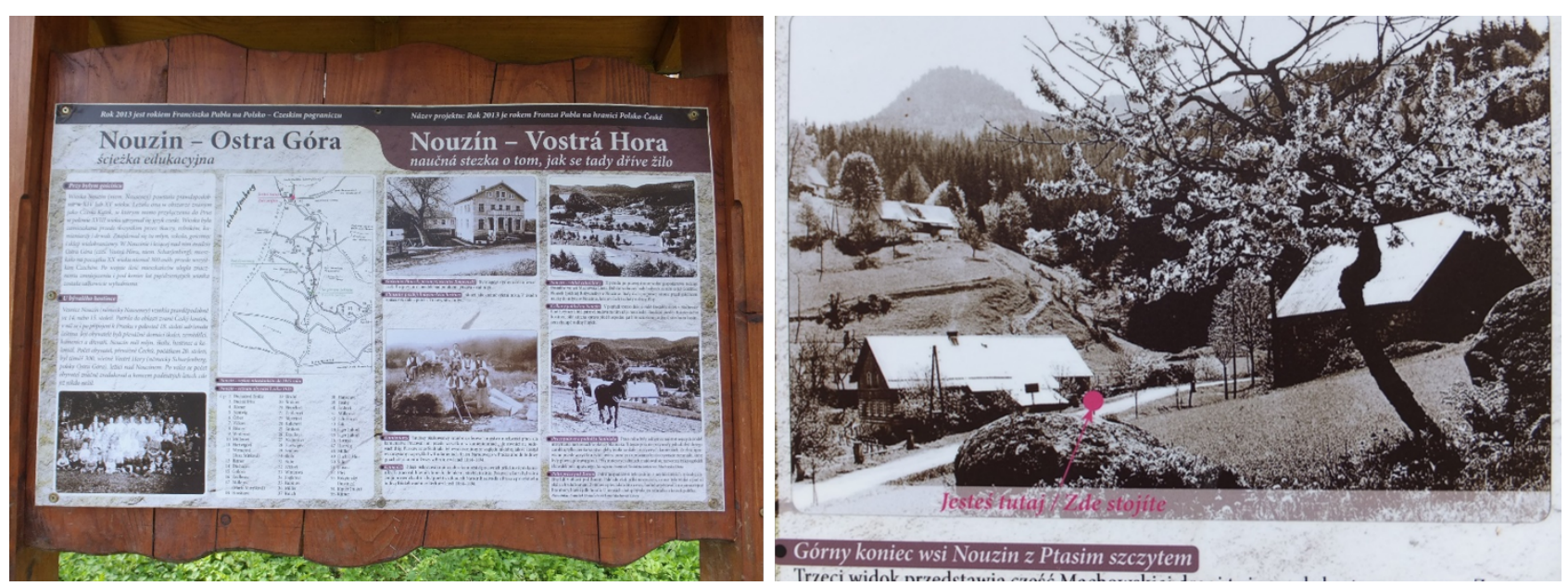

Fig. 5 Information boards along the historical trail „Nouzin-Ostra Góra”. Source: photo by A. Latocha 2018

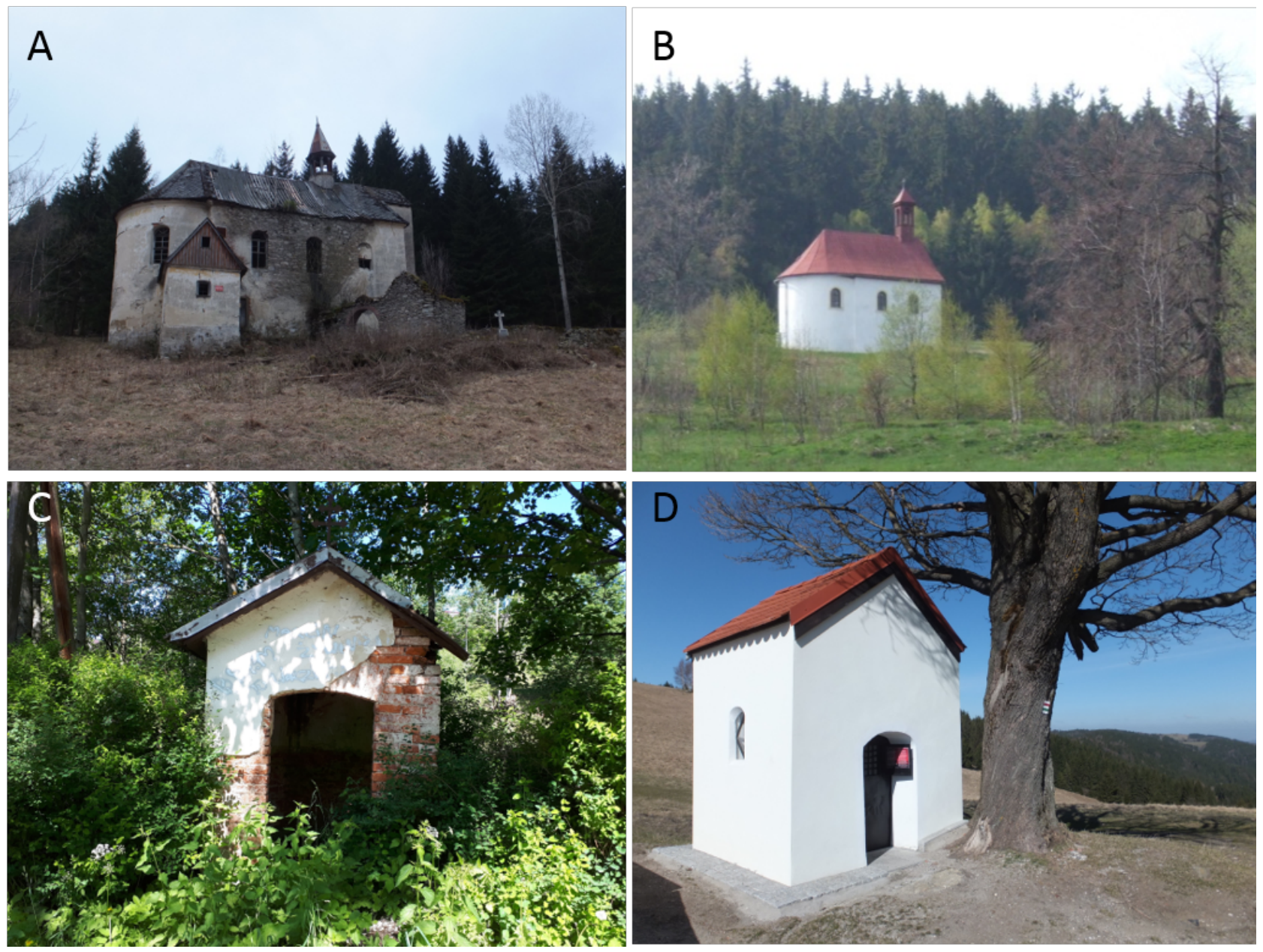

Fig. 6 Diverse state of preservation of the sacral architecture. A - Janowa Góra, B - Wrzosówka, C - Jodłów, D - Biała Woda. Source: photo by A. Latocha 2018-2019

\subsection{Villages for sell}

In the Kłodzko region a new phenomenon can be observed which is exceptional at the country scale, although it is common in other countries like Italy and Spain (Bendix 2019; Devereux 2019). In the recent years the local governments tried to sell the entire areas of the deserted villages to single investors. The first abandoned village to be sold was Rogóżka in 2016. There are no new invest- 


\section{Sciendo}
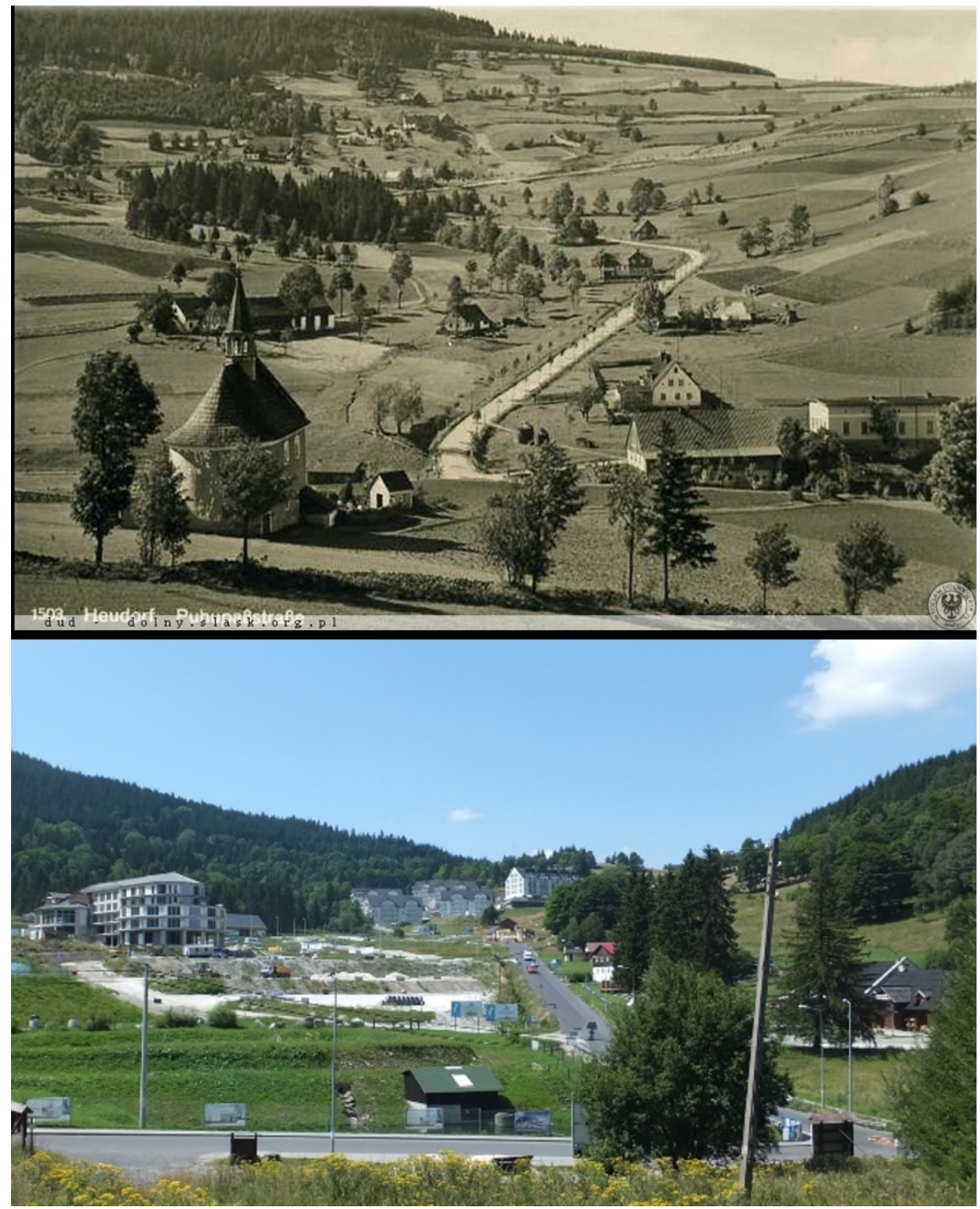

Fig. 7 Transformation of Sienna village - pre-war period and nowadays. Source: polska-org.pl (historical photo) and A. Latocha (2019)

ments there yet, however, the existing spatial development plan allows the construction of housing and infrastructure for permanent residence, recreation, sport and services. One can probably expect that the area of the deserted village will be turned into a tourist/sport/conference/spa complex, especially that it is located in the close vicinity of the Czarna Góra ski center. In the case of the second deserted village (Wrzosówka), after many years of effort, the local government did not succeed to sell it to one investor and eventually the land of the former village was divided into many plots for sell to individual owners (Fig. 3). There are already first new houses being constructed at present. In the case of the third village (Piaskowice) a large part of it was sold to a single investor while the remaining grounds were bought by individual private owners. 


\section{Discussion}

The Table 2 shows seemingly contradictory results such as both re-wilding and stopping/reduction of the secondary succession occurring in almost all the depopulated villages. However, it represents very well the diversity of the current transformations which can take place in different parts of the village. Usually, upper parts of the villages are subject to further encroachment of shrubs and trees while lower areas have been returned to use as pastures and hay meadows. In some places the patches of continuous re-wilding and the restored agricultural use have a much more complex pattern representing a mosaic of different land uses (Fig. 3). This pattern is related to the individual owners' decisions rather than to the environmental constraints. Similarly, in the same village the construction of new houses can be observed in one part of the settlement while in the other part the succession of vegetation has still been progressing into the abandoned fields. The restoration of the sacral landscape is also spatially very diverse even within the boundary of one village. It refers mainly to the small-scale sacral architecture along roadsides, such as crosses, chapels and statues of the saints. Even the neighboring sites can be in different state of preservation. Probably it also reflects very individual decisions of the owners of the nearby homesteads to get involved or not in the renovation and maintenance of the sacral site. What might be surprising is the fact, that there are abandoned churches which are in ruins nowadays although they are located within the villages which still exist (Marcinków, Janowa Góra). At the same time there are churches which have been renovated and returned to their sacral functions although they are located in the remote places with no permanent inhabitants (Wrzosówka, Karpno). Similar phenomenon is observed, among others, in Czechia, as presented on the example of the former famous Skoky pilgrimage site. It was abandoned but it is still visited although its original symbolic value has been re-interpreted for the current needs of the visitors, which is not only the sacral but also social and cultural aim of visiting (Kučera \& Kučerová 2012).

The examples presented above prove a high spatial diversity of the trends, which are currently occurring in the deserted areas. In contrast, other processes, such as the development of the new largescale tourist infrastructure or selling the entire village probably for the same purpose, are centralized only in one major location (Czarna Góra sport cen- ter), which covers four neighboring, highly depopulated or deserted villages. Although the construction of large-scale tourist infrastructure is limited to one location, it has a huge potential to entirely transform the landscape of the depopulated areas. The visual effects of these transformations are much more striking than the much more common construction of new single-family houses or development of the secondary succession. They change the function of the land use completely and the traces of the past cultural landscape are either destroyed, removed or are overwhelmed so much by the new constructions that they are hardly readable in the landscape and they lose their cultural, and spatial context (Fig. 7). According to Antrop (2002), this can be the example of the extreme contrasts in the landscape, where new urban-like constructions related to tourism infrastructure are located within the traditional rural landscapes, disturbing their spatial order and harmony.

A characteristic feature of the highly depopulated and deserted villages in the Kłodzko region is that most of them are currently located in areas covered by various forms of nature protection. The same trend was noted in the resettled borderland in Czechia, where more than $40 \%$ of the resettled land is now included in some type of protected areas (Kučera et al. 2008). Additionally, the few settlements that are located outside the protected areas have also high landscape and natural values, primarily due to the mosaic pattern of their land use, including various stages of secondary succession of vegetation.

Areas with a high number of ecotones and biotopes, i.e. traditional cultural landscapes, are generally characterized by a high degree of biodiversity (Špulerová et al. 2010; Agnoletti 2014) . As a result of the abandonment, the depopulated areas have become very valuable in terms of nature, despite prior intensive human impact. It refers mainly to the rich-species grasslands which developed on the abandoned arable land - grasslands are considered as hotspots of biodiversity in Europe (Cvitanović et al. 2017). Extensive land use (hay meadows, cattle grazing) re-introduced in many areas as part of the agri-environmental programs (since 2004), is conducive to maintaining not only ecological but also landscape diversity and openness. Nevertheless, the geo-botanical surveys proved that the abandoned settlements are able to maintain their biodiversity even long after the succession has taken over (Latocha et al. 2019). However, this does not change the fact that for over a century of the ongoing depopulation trend, some other areas of former villages have 
now become forested and gradually lost their biodiversity, becoming a "new wilderness" (Bičik et al. 2015). This observations are in line with the contradictory evaluations of the re-vegetation of the abandoned areas, which is perceived by some authors as the positive effects, and by the others - as the negative phenomena (Lasanta et al. 2015). However, it should be noted that the recent restoration and current maintenance of many open grasslands are entirely related to the support by the EU subsidies under the agro-environmental schemes, which is typical for other countries as well (e.g. Špulerová et al. 2010; Súl'ovský et al. 2017). It can be expected that without the subsidies the land will be abandoned once more and the bio-cultural values of the traditional rural landscape will be threatened again (Renwick et al. 2013).

The various forms of nature protection unfortunately are not fully able to limit the negative trends, such as excessive development of construction or the lack of adaptation of new buildings to traditional regional architecture. This is possible only within the Stołowe Mountains National Park where the constraints for new commercial investments are the strongest ones. Thanks to these limitations the remains of the past cultural landscapes are very well preserved in many areas within the National Park (Migoń \& Latocha 2013). However, within other protected areas, such as landscape parks, areas of the protected landscape or Nature2000, the restrictions are not that strict and these areas - due to their high recreational and touristic values - are recently subject to strong investment pressure both for individual investors and for large-scale infrastructure.

Regarding the rich testimony of the past cultural landscapes in the deserted villages in the Kłodzko region, the amount of the educational initiatives, such as educational paths or information boards promoting the cultural heritage of the past, seems still largely insufficient, especially when compared with the diverse revitalization projects of abandoned villages in other countries (Filipe \& Mascarenhas 2011; Kučera \& Kučerová 2012; Di Figlia 2016; Güler \& Kâhya 2019). Only one of the two educational paths (in Czerwony Strumień) is used on a regular basis by the teachers of the nearby school as a part of the regional education for local children. The other one, which is located within the National Park (Ostra Góra) in a remote area, is visited by the wandering tourists only by the way, when hiking along the tourist trail, which runs through the abandoned village, but it is rather not the aim of the excursion itself. Similarly, the two eco-museums are visited only when passing through the villages and not as the main aims of the visit to these areas. Moreover, the explanation boards were created a few years ago and they would need a renovation by now.

However, given the very recent time since such projects started to develop, they can be interpreted as the first signals of the change of perception of the abandoned settlements and the pre-war heritage. It gives hope that such initiatives will be further developed not only for the regional education of school children, but also for all local inhabitants, including the numerous new-settlers from cities and part-time residents, as well as for tourists who visit the Kłodzko region in large numbers. The increase of such educational and commemorative initiatives related to the past cultural heritage (which is often perceived as a dissonant heritage) has also been noted in the neighboring Czechia with similar political history of depopulation and socioeconomic transformations after the 1989 (Spurný 2006; Kučera \& Chromý 2012; Kučera \& Kučerová 2012). The organization of diverse cultural events promoting the values of deserted settlements and the remains of past cultural landscapes has become a new tradition in some of the depopulated regions in Czechia. For example land art festivals have been regularly organized in Ralsko (https://www.landart-ralsko.com/en/) and in Králův Mlýn (https://konigsmuhle.cz/). Unfortunately, such cultural and educational cyclic or one-off events like lectures and exbibitions dedicated to the deserted villages have not yet been organized in the Kłodzko region. However, it might be expected that they can develop in the future based on the recent observations of the increase in the numbers of the new local educational initiatives, increase in the interest in local history, as well as the need to develop the new tourist products. There is already one example of such an initiative in other part of the Polish Sudetes, in highly depopulated town of Miedzianka, which became famous thanks to a non-fiction book "Miedzianka - history of a disappearance" (Springer 2011) and the reportage festival has been organized annually since 2017 in this place (https://www.facebook.com/MiedziankaFest/).

The analysis of the spatial development documents and plans show that the new investments, such as single-family houses and tourist infrastructure, may largely increase in the near future even in the deserted villages. In this context, the former settlement would be restored. However, it means neither the restoration of its previous (pre-war) functions (agriculture, industry, crafts, weaving) nor an increase in the number of inhabitants. Currently, a significant part of the depopulated villages be- 
gin to function primarily as tourist attractive areas and a large share of the new houses serve recreational purposes as second homes, guesthouses or homes for rent, which is a typical trend in many regions with attractive landscapes. The recreational and tourism functions are very often proposed as the most common strategies for revival of the abandoned villages in various countries (Filipe \& Mascarenhas 2011; Di Figlia 2016; Jaszczak et al. 2018). Unfortunately, many of the new buildings in the study area do not follow the traditional style of the regional architecture and they are not well integrated into the landscape which disturb the spatial order of the cultural landscape and landscape character. It is in contrast with the neighboring Czech villages where most of the buildings, including the new ones, preserve the outlines of the traditional architecture. It should be mentioned that the development of recreational buildings on the Polish and Czech side of the border had a completely different course. On the Czech side, the popularity of second homes has been recorded since the 1960s, and - in contrast to the Polish side - in most cases they were old, pre-war buildings (Fialová 2003; Vágner et al. 2011). This allowed to maintain traditional buildings and prevent mass construction of the new buildings, which is observed in the recent years on the Polish side where the second homes "boom" started only in the 2000s.

\section{Conclusions}

The abandoned villages in the Kłodzko region follow diverse trends in their current transformations, which are also observed or proposed as the strategies for conservation or revival in other abandoned areas (Di Figlia 2016, Güler \& Kâhya 2019). The processes occurring in the studied villages are spatially very diverse, in terms of both the type of phenomena and their dynamics. These processes often co-occur with each other and they are diverse in different parts of the village. In contrast, some villages are characterized by only one of the presented phenomena. These various trends show how diverse the current development paths of the depopulated areas can be. The very large variety of socio-economic processes observed nowadays in the abandoned areas results in various effects of landscape transformations. The basic landscape change that can already be observed in many of the depopulated villages is the transformation of the settlement structure. In the future, one can expect this trend to increase.
The results of the presented study prove that in the current transformations of the deserted villages the main focus is on local economy and/or nature protection while the cultural landscape of the abandoned areas is hardly appreciated as an important value itself. Although there are some recent positive signs of an increase in the interest in the history of the region and of the re-appreciation and promotion of the pre-war heritage, there are still numerous sites which are forgotten and neglected. There are many more places that would ideally serve educational purposes to make both local inhabitants and tourists aware of the complex history of the region and the richness of the preserved cultural landscape, which reflect the close relationship between past human activities and the resulting landscape features.

It can be expected that the potential paths of further transformations of depopulated areas would be multidirectional with the tendency to process polarization. While some areas will be subject to an increased human pressure, especially due to the new developments in housing, the other areas would remain out of the way allowing for using their potential as "archives" of traditional cultural landscapes. Therefore one can expect that the increasing loss of the cultural landscapes in some places will be accompanied with the increasing appreciation of the cultural heritage preserved in the landscape in other sites.

\section{Acknowledgements}

Part of the research was financially supported by the National Science Centre in Poland by project no. 2017/27/B/HS4/01220. The author is grateful to the anonymous reviewers for their valuable suggestions, which allowed to improve the quality of the paper. I would also like to thank Małgorzata Wieczorek for her help with the elaboration of the map.

\section{References}

Affek A N, Zachwatowicz M, Solon J (2020) Long-term landscape dynamics in the depopulated Carpathian Foothills: a Wiar river basin case study. Geographia Polonica 93(1): 5-23.

Agnoletti M (2014) Rural landscape, nature conservation and culture: Some notes on research trends and management approaches from a (southern) European perspective. Landscape and Urban Planning 126: 66-73.

Antrop M (2002) Rural-urban conflicts and opportunities. In: Jongman R (ed) The new dimensions of the European landscape. Proceedings of the Frontis workshop on the future of the European cultural landscape. Ghent University, Ghent, pp. 83-91.

Antrop M (2005) Why landscapes of the past are important for the future. Landscape and Urban Planning 70: 21-34. 


\section{sciendo}

Bendix A (2019) Italy's abandoned villages plan to save themselves from ruin by selling homes for $\$ 1$ or less. Business Insider. <https://www.businessinsider.com/italian-villages-sellingdollar-homes-2019-2?IR=T>

Bernatzky A (1984) Lexicon der Grafschaft Glatz. Marx Verlag, Leimen.

Bezák P, Mitchley J (2014) Drivers of change in mountain farming in Slovakia: from socialist collectivisation to the Common Agricultural Policy. Regional Environmental Change 14: 1343-1356.

Bičík I, Gabrovec M, Kupková L (2019) Long-term land-use changes: a comparison between Czechia and Slovenia. Acta Geographica Slovenica 59(2): 91-105.

Bičík I, Kupková L, Jeleček L, Kabrda J, Štych P, Janoušek Z, Winklerová J (2015) Land Use Changes in the Czech Republic 1845-2010. Socio-Economic Driving Forces. Springer, Cham, Heidelberg, New York, Dordrecht, London.

Boesch M, Renner E, Siegrist D (2011) Strategies for preventing the decline of peripheral areas. Journal of Alpine Research 99(1). doi: https://doi.org/10.4000/rga.1386

Bucała-Hrabia A (2017) Long-term impact of socio-economic changes on agricultural land use in the Polish Carpathians. Land Use Policy 64: 391-404.

Chachaj J (1978) Problem wsi zanikającej. Acta Universitatis Wratislaviensis 324, Prace Instytutu Geograficznego, seria B (2): 119-123.

Ciok S (1991) Sudety. Obszar problemowy. Acta Universitatis Wratislaviensis 1236, Studia Geograficzne 51, Wrocław.

Collantes F, Pinilla V (2011) Peaceful surrender: the depopulation of rural Spain in the twentieth century. Cambridge Scholars Publishing, Newcastle upon Tyne.

Cvitanović M, Lučev I, Fürst-Bjeliš B, Slavuj Borčić L, Horvat S, Valožić L (2017) Analyzing post-socialist grassland conversion in a traditional agricultural landscape - case study Croatia. Journal of Rural Studies 51: 53-63.

De Haas H (2011) Mediterranean migration futures: Patterns, drivers and scenarios. Global Environmental Change 21: S59-S69.

Devereux Ch (2019) Ghost villages are for sale in Spain. Bloomberg, 29.03.2019. <https://www.bloomberg.com/news/articles/2019-03-29/ghost-villages-for-sale-as-spain-fights-ruraldesertification>

Di Figlia L (2016) Turnaround: abandoned villages, from discarded elements of modern Italian society to possible resources. International Planning Studies 21(3): 278-297.

Fialová D (2003) Regional differentiation of second housing transformation in Czechia. Acta Universitatis Carolinae, Geographica 1: 59-65.

Filipe M, de Mascarenhas J M (2011) Abandoned villages and related geographic and landscape context: guidelines to natural and cultural heritage conservation and multifunctional valorization. European Countryside 1: 21-45.

Flaga M, Wesołowska M (2018) Demographic and social degradation in the Lubelskie Voivodeship as a peripheral area of East Poland. Bulletin of Geography. Socio-economic Series 41(41): 7-27.

Foucher A, Evrard O, Chabert C, Cerdan O, Lefčvre I, Vandromme R, Salvador-Blanes S (2019) Erosional response to land abandonment in rural areas of Western Europe during the Anthropocene: A case study in the Massif-Central,
France. Agriculture, Ecosystems and Environment 284: https://doi.org/10.1016/j.agee.2019.106582

Güler K, Kâhya Y (2019) Developing an approach for conservation of abandoned rural settlements in Turkey. ITU A/Z 16(1): 97-115.

Herzig A, Ruchniewicz M (2008) Dzieje Ziemi Kłodzkiej. Oficyna Wydawnicza Atut, Hamburg-Wrocław.

Hons O (2014) Zaniklé obce kolem Ralska. TYPOS, Ralsko.

Jaszczak A, Kristianova K, Vaznonienė G, Zukovskis J (2018) Phenomenon of abandoned villages and its impact on transformation of rural landscapes. Management Theory and Studies for Rural Business and Infrastructure Development 40(4): 467-480.

Kučera Z, Chromý P (2012) Depopulation, resettlement and landscape changes in the peripheries of the Czech borderland. In: Paniagua A, Bryant R, Kizos T. (eds) The Political Ecology of Depopulation: Inequality, Landscape and People. Ceddar, Zaragoza, pp. 191-213.

Kučera Z, Kučerová S (2012) Historical geography of persistence, destruction and creation: the case of rural landscape transformations in Czechia's resettled borderland. Historická Geografie 38(1): 165-184.

Kučera Z, Kučerová-Kuldová S, Chromý P (2008) Landscape heritage between areal preservation and areal development the case of Czechia. Geographia Polonica 81: 5-23.

Kutkowska B, Berbeka T (2014) Wspieranie rolnictwa na obszarach o niekorzystnych warunkach gospodarowania (ONW) na przykładzie rolnictwa Sudetów. Roczniki Naukowe Ekonomii Rolnictwa i Rozwoju Obszarów Wiejskich 101(2): 55-69.

Lasanta T, Arnáez J, Pascual N, Ruiz-Flaño P, Errea M P, LanaRenault N (2017) Space-time process and drivers of land abandonment in Europe. Catena 149: 810-823.

Lasanta T, Nadal-Romero E, Arnáez J (2015) Managing abandoned farmland to control the impact of re-vegetation on the environment. The state of the art in Europe. Environmental Science \& Policy 52: 99-109.

Latocha A (2015) Recovering the lost landscapes of abandoned villages in the Sudetes Mountains, southwest Poland. In: Ivanišević V, Veljanovski T, Cowley D, Kiarszys G, Bugarski I (eds) Recovering lost landscapes. Institute of Archaeology, Monographs 58, Aerial Archaeology Research Group Occasional Publication 6, Belgrad, pp. 45-56.

Latocha A (2017) Odradzanie wsi? Przemiany ludnościowoosadnicze na ziemi kłodzkiej w okresie powojennym. Studia Obszarów Wiejskich 48: 29-50.

Latocha A, Reczyńska K, Gradowski T, Świerkosz K (2019) Landscape memory in abandoned areas - physical and ecological perspectives (Central European mountains case study). Landscape Research 44: 600-613.

Latocha A, Szymanowski M, Jeziorska J, Stec M, Roszczewska M (2016) Effects of land abandonment and climate change on soil erosion. An example from depopulated agricultural lands in the Sudetes Mts., SW Poland. Catena 145: 128-141.

Latocha A, Szymanowski M, Wieczorek M (2018) Wyludnianie powiatu kłodzkiego - przestrzenne zróżnicowanie i uwarunkowania. Przeglad Geograficzny 90(2): 241-266.

Li Y, Westlund H, Liu Y (2019) Why some rural areas decline while some others not: An overview of rural evolution in the world. Journal of Rural Studies 68: 135-143.

Lieskovský J, Bezák P, Špulerová J, Lieskovský T, Koleda P, Dobrovodská M, Bürgi M, Gimmi U (2015) The abandonment of traditional agricultural landscape in Slovakia - Analysis of extent and driving forces. Journal of Rural Studies 37: 75-84. 


\section{Sciendo}

MacDonald D, Crabtree J R, Wiesinger G, Dax T, Stamou N, Fleury P, ... Gibon A (2000) Agricultural abandonment in mountain areas of Europe: environmental consequences and policy response. Journal of Environmental Management 59(1): 47-69.

Mares P, Rasin R, Pipan P (2013) Abandoned Landscapes of Former German Settlement in the Czech Republic and in Slovenia. In: Rotherham ID (ed) Cultural Severance and the Environment. Springer, Dordrecht, pp. 289-309.

McLeman R A (2011) Settlement abandonment in the context of global environmental change. Global Environmental Change 21: $108-120$.

Merino F, Prats M A (2020) Why do some areas depopulate? The role of economic factors and local governments. Cities 97. doi: 10.1016/j.cities.2019.102506

Migoń P, Latocha A (2013) Human Interactions with the Sandstone Landscape of Central Sudetes. Applied Geography 42: 206-216.

Mikusek R (1996) Ptaki lęgowe Gór Bystrzyckich. Ptaki Śląska 11: 81-114

Miszewska B (1993) Problemy ludnościowe Sudetów. Acta Universitatis Wratislaviensis 1343, Studia Geograficzne 58: 33-56.

Nadolna L (2012) Wartości przyrodnicze sudeckich użytków zielonych o zróżnicowanym sposobie użytkowania na tle warunków siedliskowych i fizjograficznych. Woda-ŚrodowiskoObszary Wiejskie 12, 4 (40): 181-201.

Pinto-Correia T, Guiomar N, Guerra C A, Carvalho-Ribeiro S (2016) Assessing the ability of rural areas to fulfil multiple societal demands. Land Use Policy 53: 86-96.

Plieninger T, Draux H, Fagerholm N, Bieling C, Bürgi M, Kizos T, ... Verburg P H (2016) The driving forces of landscape change in Europe: A systematic review of the evidence. Land Use Policy 57: 204-214.

Renwick A, Jansson T, Verburg P H, Revoredo-Giha C, Britz W, Gocht A, McCracken D (2013) Policy reform and agricultural land abandonment in the EU. Land Use Policy 30: 446-457.

Rodriguez-Soler R, Uribe-Toril J, De Pablo Valenciano J (2020) Worldwide trends in the scientific production on rural depopulation, a bibliometric analysis using bibliometrix R-tool. Land Use Policy 97. doi: https://doi.org/10.1016/j.landusepol.2020.104787

Semotanová E (2009) Kladsko jako barokní komponovaná krajina. Historická geografie 35, 1: 161-198.

Semotanová E et al. (2015) Kladsko. Historickogeografický lexikon. Historický Ústav AV ČR, seria A, 53, Praha-KłodzkoWrocław.
Shrinking regions: a paradigm shift in demography and territorial development. Study (2008) European Parliament, Brussels.

Skokanová H, Faltan V, Havlíček M (2016) Driving forces of main landscape change processes from past 200 years in Central Europe-differences between old democratic and post-socialist countries. Ekológia 35(1): 50-65.

Springer F (2011) Miedzianka - history of a disappearance. Regan Arts.

Špulerová J, Dobrovodská M, Štefunková D (2010) Driving forces, threats and trends relating to mosaics in agricultural landscape in Slovakia. Journal of Landscape Ecology 3(2): 59-72.

Spurný M (ed) (2006) Promĕny sudetské krajiny. Antikomplex, Nakladatelství Českého lesa, Domažlice.

Štastná M, Vaishar A, Vavrouchová H, Ševelová M, Kozlovská S, Doskočilová V, Lincová H (2015) Changes of a rural landscape in Czech areas of different types. European Countryside 2: 111-133.

Súlovský M, Faltan V, Skokanová H, Havlíček M, Petrovič F (2017) Spatial analysis of long-term land-use development in regard to physiotopes: case studies from the Carpathians. Physical Geography 38(5): 470-488.

Szmytkie R, Tomczak P (2015) Współczesne tendencje zmian ludnościowych i funkcjonalnych na obszarach wiejskich Ziemi Kłodzkiej. Studia Obszarów Wiejskich 37: 181-194.

Szmytkie R, Tomczak P (2017) Revival of rural settlements in Kłodzko land. Geographia Polonica 90, 3: 319-333.

Telbisz T, Brankov J, Ćalić J (2020) Topographic and lithologic controls behind mountain depopulation in Zlatibor District (Western Serbia). Journal of Mountain Science 17(2): 271-288.

Vágner J, Müller D K, Fialová D (2011) Second home tourism in light of the historical-political and socio-geographical development of Czechia and Sweden. Geografie 116(2): 191-210.

Wang C, Zhang Y, Yang Y, Yang Q, Hong J (2019) What is driving the abandonment of villages in the mountains of Southeast China? Land Degradation \& Development 30(10): 1183-1192.

Wolski J (2016) The landscape of abandoned villages in the Western Bieszczady: the problem of definition and classification. Geographia Polonica 89(3): 371-387.

Zagożdżon A (1990) Wybrane problemy ludnościowe Sudetów na tle rozwoju regionalnego. Studia KPZK PAN 96: 95-111. 